Research Article

\title{
Effect of $A B O$ blood group on survival of resected lung cancer patients: a retrospective study
}

\begin{abstract}
Introduction: A positive correlation between $\mathrm{ABO}$ blood group and survival has been suggested in several malignancies. The aim of this study is evaluate the effect of ABO blood group on survival of surgically resected lung cancer patients.

Materials and methods: A total of 139 patients with lung cancer who underwent curative surgery from January 2009 to November 2010 were enrolled in this retrospective study. Besides clinicopathological prognostic factors, we evaluated the prognostic value of $\mathrm{ABO}$ blood type on survival. Univariate analysis was performed by Kaplan-Meier survival analysis and multivariate analysis by Cox Regression Hazard model to measure 5-year Overall survival (OS), Progression free survival (PFS), Distant metastasis free survival (DMFS), Relapse free survival(RFS).

Results: The median follow-up period of 139 lung cancer patients was 37 months. The distribution of $\mathrm{ABO}$ blood type were $16 \mathrm{AB}$ blood type patients (11.5\%), $34 \mathrm{~A}$ blood group (24.5\%), 42 blood group B (30.2\%) and 47 blood group O (33.8\%) respectively. Pearson Chi square test showed that $\mathrm{ABO}$ blood group was significantly associated with age $(\mathrm{P}=0.015)$, T stage $(\mathrm{P}=0.047)$ and histological grades $(\mathrm{P}=0.001)$, whereas there was no significant association $(\mathrm{P}>0.05)$ between $\mathrm{ABO}$ blood group and gender, smoking, alcohol, lymphnode status, tumor differentiation, tumor size and pathological type. In the Kaplan-Meier analysis ABO blood type was associated with OS, PFS, DMFS and RFS. The mean survival months were 67.9, 52.2, 54.2, 47.3 for blood type $\mathrm{AB}, \mathrm{A}, \mathrm{B}$ and $\mathrm{O}$ patients respectively $(\mathrm{P}=0.024)$. The mean survival months were $63.3,51.3,47.2,42.2$ for blood type AB, A, B and $O$ patients respectively $(0.025)$. The mean survival months of distant metastasis free survival were 62.5 , 59.6, 53.1, 43.6 months for $\mathrm{AB}, \mathrm{A}, \mathrm{B}$ and $\mathrm{O}$ blood type patients respectively $(\mathrm{P}=0.029)$.The mean survival months of relapse free survival were 62.4, 50.6, 60.9, 47.4 months for $\mathrm{AB}$, $\mathrm{A}, \mathrm{B}$ and $\mathrm{O}$ blood type patients respectively $(\mathrm{P}=0.034)$. Multivariate analysis also revealed that $\mathrm{ABO}$ blood type was significantly associated with $\mathrm{OS}(\mathrm{HR}=0.159$ with $95 \% \mathrm{CI}=0.046$ $0.543, \mathrm{P}=0.003)$, $\mathrm{PFS}(\mathrm{HR}=0.313$ with $95 \% \mathrm{CI}=0.122, \mathrm{P}=0.015)$, $\mathrm{DMFS}(\mathrm{HR}=0.301$ with $95 \% \mathrm{CI}=0.160-0.568, \mathrm{P}<0.001)$ and $\mathrm{RFS}(\mathrm{HR}=0.483$ with $95 \% \mathrm{CI}=0.274-0.852, \mathrm{P}=0.012)$
\end{abstract}

Conclusion: Blood type $\mathrm{AB}$ is a favorable prognostic factor for patients with lung cancer than non- $\mathrm{AB}$ blood type (blood type $\mathrm{A}, \mathrm{B}$ or $\mathrm{O}$ ).

Keywords: lung cancer, $\mathrm{ABO}$ blood group, prognosis, survival
Volume 4 Issue I - 2016

\author{
Effat Un Nesa,' Cong Wang,' Chowdhury \\ Sumon Rahman, ${ }^{2}$ Han Zhang,' Xiao Yue \\ Liu,' Ying Sun,' Peng Xiang Chen,' Li Jingyi,' \\ Misbahul Ferdous, ${ }^{3}$ Yufeng Cheng' \\ 'Department of Radiation Oncology, Qilu Hospital of Shandong \\ University, People's Republic of China \\ ${ }^{2}$ Department of Endocrinology, Qilu Hospital of Shandong \\ University, People's Republic of China \\ 3Department of Cardiology, Shandong provincial Hospital of \\ Shandong University, People's Republic of China
}

Correspondence: Yufeng Cheng, Department of Radiation Oncology, Qilu Hospital of Shandong University, Jinan, Shandong, 2500 I2, People's Republic of China,, Tel 86-53I-8216983I, Fax 86-53I-86927544, Email qlyufengcheng@hotmail.com

Received: January 01, 2016 | Published: January 08, 2016

\section{Introduction}

Lung cancer is the most deadly type of cancer that represents a major public health problem and it still remains the leading cause of cancer related death worldwide. ${ }^{1}$ Despite diverse treatment methods including chemotherapy, surgery, radiotherapy and targeted therapies are used, the outcome of all type of lung cancers are disappointing, with 5 -year overall survival rates estimating to $17.1 \%$ for non-small cell lung cancer(NSCLC) and $6.1 \%$ for small cell lung cancer. ${ }^{2}$ Clinically it proves that lung cancer can metastasize to specific target organs, such as brain, liver, adrenal glands and bone. Recent findings have revealed that the prognosis of lung cancer patients is not only determined by the characteristics of tumors, but also the patients related factors. Identification of biomarkers that are readily available, inexpensive and reproducible could improve the prognosis of patients and help physicians in providing individualized therapies.

The chromosome $9 \mathrm{q} 34$ consists of the ABO gene which encodes glycosyl Transferase that catalyse the transfer of nucleotide donor carbohydrates to the $\mathrm{H}$ antigen and forms the $\mathrm{ABO}$ blood group system.3 ABO blood type antigens are expressed on the surface of red blood cells and other tissue types including cells from the gastrointestinal tract. The correlation between $\mathrm{ABO}$ blood group system and cancer has been a subject of interest since the mid 1900s. Laboratory investigations have provided several plausible mechanisms to explain the observed association between $\mathrm{ABO}$ blood group system and cancer. These proposed mechanisms involve inflammation, immune surveillance for malignant cells, intercellular adhesion and membrane signaling. ${ }^{4-6}$ Recently, the positive association between $\mathrm{ABO}$ blood type and survival has been evaluated in several malignancies, including colon cancer, pancreatic cancer, nasopharyngeal carcinoma, esophageal cancer, breast cancer, skin cancer, renal cell carcinoma and gastric cancer. ${ }^{7-14}$ Although the study by Lee et al. established the survival of NSCLC patients who received curative surgery within the context of $\mathrm{ABO}$ blood group, the aim of their study was to investigate the prognostic role of expression of blood group antigen $\mathrm{A}$ in tumor cells. ${ }^{15}$ However, to date, the controversy still remains over the clinical value of $\mathrm{ABO}$ blood group to predict the prognosis of NSCLC. ${ }^{16}$ Therefore, the aim of this retrospective study was to clarify the correlation between $\mathrm{ABO}$ blood group system and survival analysis among all type of lung cancer patients who underwent curative surgery as their primary treatment. 


\section{Materials and methods}

\section{Patients selection and data collection}

This retrospective clinical study included 440 consecutive all type of lung cancer patients who underwent curative surgery (lobectomy, pneumonectomy) at Qilu Hospital of Shandong University from January 2009 to November 2010. Patients were eligible for the study if they met the following criteria:(1)Resected lung cancer with lobectomy or pneumonectomy and lymphnode dissection, (2) negative surgical margin (R0) and (3)No preoperative radiotherapy or chemotherapy. The main exclusion criteria were perioperative death and previous malignancies. The patients criteria which was not favorable with inclusion criteria that excluded from study group. Furthermore, patients without available data, death date and follow up were excluded. Hence after the rigorous exclusion process, a total of 139 patients were enrolled in our study. The protocol of the study was approved by the Institutional Ethics Committee of the Qilu Hospital of Shandong University. The extent of the disease was determined by TNM staging according to the new IASLC staging system.17 Informed consent was obtained from all individual participants in the study. Data were collected from medical records in hospital database. Clinicopathological factors were used to assess the risk of death. Factors examined included age, gender, smoking habit, alcohol intake, tumor size, pT stage, lymphnode status, tumor differentiation, pathological type and $\mathrm{ABO}$ blood group.

\section{Treatment and follow up}

All patients underwent curative surgery, Lobectomy or pneumonectomy was performed according to the location or size of the lung neoplasm. Patients who had undergone exploratory thoracotomy without resection were excluded from our study. Systematic mediastinum lymph node dissection was performed in all patients. All patients received standardized follow-up at a 3-month interval for the first 2 years after operation, a 6-month interval in the third year and yearly thereafter. Evaluation comprised a physical examination, complete blood count, chest computed tomography, brain magnetic resonance imaging and abdominal ultrasound.

The following endpoints were estimated: Relapse-free survival (RFS), was defined as the duration from the date of surgery to the date when any relapse was diagnosed. Distant metastasis-free survival (DMFS) covered the date of definitive surgery to the confirmation date of diagnosis of distant metastasis. Relapse-free survival (RFS) was defined as the time from surgery to any recurrence. Overall survival (OS) was calculated as the time from the date of surgery to death or date of last follow up.

\section{Statistical analysis}

The chi-square test was performed to evaluate the association between the clinicopathological variables and ABO blood group. All endpoints were estimated by the Kaplan-Meier survival analysis and compared by using Log-rank test. Multivariate analyses were carried out by using Cox Proportional Hazards model to identify important prognostic factors for OS, PFS, DMFS, RFS). P-values were two sided and statistical significance was accepted for P-values of $<0.05$. All statistical analyses were carried out using SPSS for Windows, Version 22 (SPSS Inc., Chicago, IL, United States).

\section{Results}

\section{Patient characteristics}

A total of 139 lung cancer patients were enrolled in our study. The baseline characteristics of the study population are listed in Table 1.The median age of the 139 patients enrolled into the study was 60 years (age range:36-85 years). The distribution of ABO blood type was 16 AB blood type patients (11.5\%), 34 A blood group (24.5\%), 42 blood group B (30.2\%), 47 blood group O (33.8\%) respectively. According to the IASLC classification criteria for lung tumors, 52 (37.4\%) of the tumors were squamous cell carcinoma, $56(40.3 \%)$ adenocarcinoma, $9(6.5 \%)$ small cell carcinoma, 9 (6.5\%) bronchoalveolar carcinoma and $13(9.4 \%)$ consisted of other types. There were $17(12.2 \%)$ well differentiated, 73 (52.5\%) moderately differentiated and 47 (33.8\%) poorly differentiated. A total of 67 patients $(48.2 \%)$ had experience of smoking and $51(36.7 \%)$ of ingesting alcohol. According to the new IASLC staging system, 43 of the cases $(30.9 \%)$ were stage T1, 51 (36.7\%) stage T2, 42 (30.2\%) stage T3, 3 (2.2\%) stage T4.Pearson Chi square test showed that $\mathrm{ABO}$ blood group was significantly associated with age $(\mathrm{P}=0.015)$, T stage $(\mathrm{P}=0.047)$ and histological grade $(\mathrm{P}=0.001)$, whereas there was no significant association $(\mathrm{P}>0.05)$ between $\mathrm{ABO}$ blood group and gender, smoking, alcohol, lymhnode status, tumor differentiation, tumor size and pathological type.

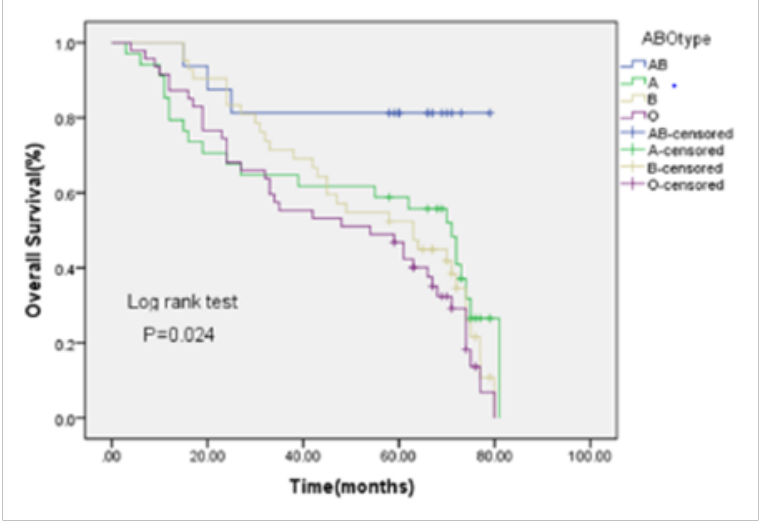

Figure IA Overall survival of lung cancer patients according to $A B O$ blood type.

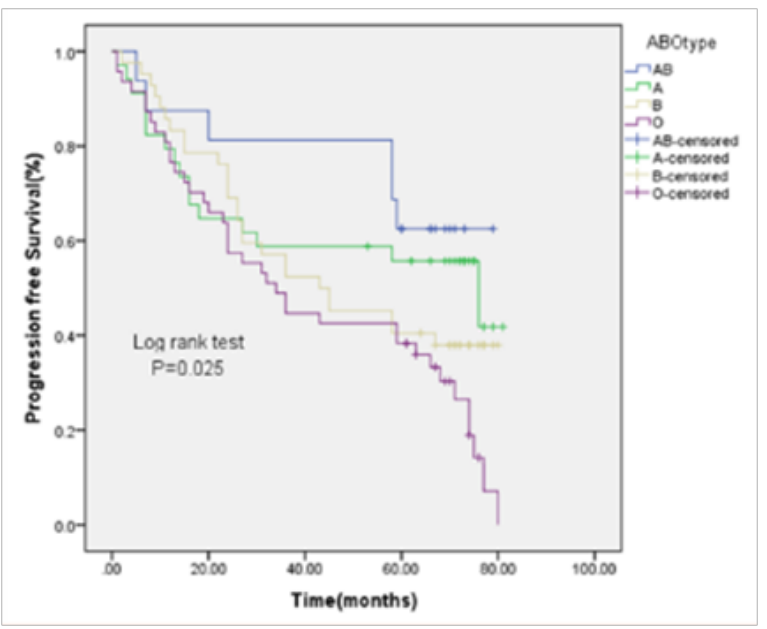

Figure IB Progression free survival of lung cancer patients according to $A B O$ blood type.

\section{Effect of $A B O$ blood group on survival}

The median follow-up period of 139 lung cancer patients was 37 months with consequently 43 patients being alive and 96 succumbing to cancer related death until the last follow-up. In the Kaplan-Meier analysis $\mathrm{ABO}$ blood type were associated with OS, PFS, DMFS, 
RFS(table 2).The 5-year overall survival rate were $81.3 \%, 32.4 \%$, $23.8 \%, 19.1 \%$ and mean survival months were $67.9,52.2,54.2$, 47.3 for blood type $\mathrm{AB}, \mathrm{A}, \mathrm{B}$ and $\mathrm{O}$ patients respectively $(\mathrm{P}=0.024$, figure 1A).The 5-year progression free survival rate were $62.5 \%$, $52.9 \%, 38.1 \%, 19.1 \%$ and mean survival months were $63.3,51.3$, 47.2, 42.2 for blood type $\mathrm{AB}, \mathrm{A}, \mathrm{B}, \mathrm{O}$ patients respectively $(\mathrm{P}=0.025$, figure 1B).The mean survival months of distant metastasis free survival were $62.5,59.6,53.1,43.6$ months for $\mathrm{AB}, \mathrm{A}, \mathrm{B}, \mathrm{O}$ blood type patients respectively $(\mathrm{P}=0.029$, figure $1 \mathrm{C})$. The mean survival months of relapse free survival were $62.4,50.6,60.9,47.4$ months for $\mathrm{AB}, \mathrm{A}, \mathrm{B}, \mathrm{O}$ blood type patients respectively $(\mathrm{P}=0.034$, figure 1D). Lymphnode status was also significantly associated with OS, PFS, DMFS and RFS and P value was $<0.001$ in all kind of survival analysis(figure 2).But tumor size was only significantly associated with $\mathrm{OS}(\mathrm{P}=0.031)$. To determine whether $\mathrm{ABO}$ blood type could serve as an independent prognostic parameter, we examined OS, PFS, DMFS, RFS using the Cox proportional hazards model(table 3).All the parameters found to be significant in the univariate analysis were further analysed by multivariate analysis and the results revealed that $\mathrm{ABO}$ blood type was significantly associated with $\mathrm{OS}(\mathrm{HR}=0.159$ with $95 \% \mathrm{CI}=0.046-0.543, \mathrm{P}=0.003), \mathrm{PFS}(\mathrm{HR}=0.313$ with $95 \% \mathrm{CI}=0.122$, $\mathrm{P}=0.015)$, DMFS(HR $=0.301$ with $95 \% \mathrm{CI}=0.160-0.568, \mathrm{P}<0.001)$ and $\mathrm{RFS}(\mathrm{HR}=0.483$ with $95 \% \mathrm{CI}=0.274-0.852, \mathrm{P}=0.012)$. We also observed that tumor size was only significantly associated with OS (HR $=0.626$ with $95 \% \mathrm{CI}=0.404-0.970, \quad \mathrm{P}=0.036)$ whereas the lymphnode status was also significantly associated with $\mathrm{OS}(\mathrm{HR}=0.395$ with $95 \% \mathrm{CI}=0.252-0.617, \mathrm{P}<0.001), \mathrm{PFS}(\mathrm{HR}=0.388$ with $95 \% \mathrm{CI}=0.244$ $0.617, \quad \mathrm{P}<0.001), \quad \mathrm{DMFS}(\mathrm{HR}=0.464$ with $95 \% \mathrm{CI}=0.303-0.711$, $\mathrm{P}<0.001)$ and $\mathrm{RFS}(\mathrm{HR}=0.377$ with $95 \% \mathrm{CI}=0.242-0.586, \mathrm{P}<0.001)$.

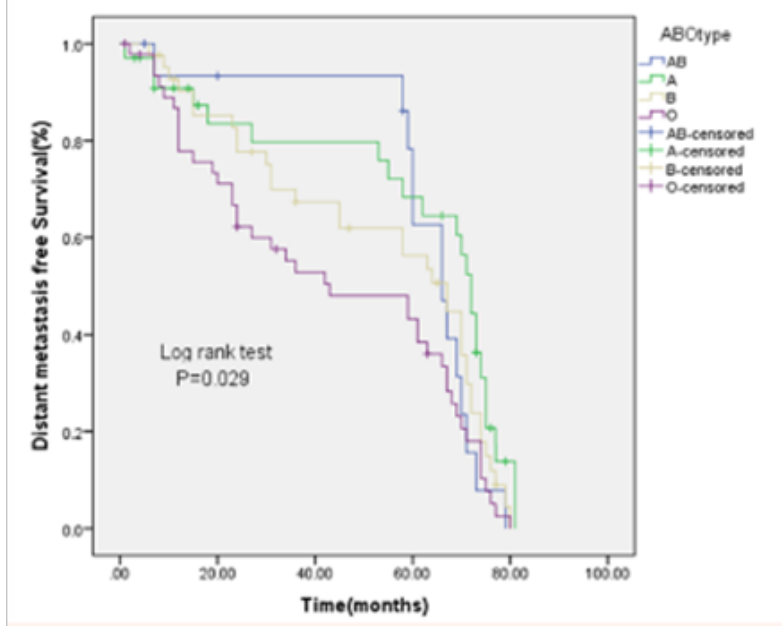

Figure IC Distant metastasis free survival of lung cancer patients according to $\mathrm{ABO}$ blood type.

\section{Discussion}

In recent years, several studies have suggested that importance of $\mathrm{ABO}$ blood group system in the development of hemostasis and neoplastic disease, because of $\mathrm{ABO}$ antigens are highly expressed on the surface of a variety of human cells and tissues. ${ }^{18}$ However, to date, association between $\mathrm{ABO}$ blood type and lung cancer survival have not been well developed. Based on its unique aetiology, patients characteristics, $\mathrm{ABO}$ blood typing and long follow-up time, the current study is first to evaluate the effect of survival of ABO blood type among patients with resected lung cancer. Among the 139 lung cancer cases examined in this retrospective study from Qilu hospital of Shandong university, we observed significantly better survival for participants with blood group $\mathrm{AB}$ than non- $\mathrm{AB}$ blood group patients(blood groups $\mathrm{A}, \mathrm{B}$ and $\mathrm{O}$ ). The worst survival was observed for participants with blood type $\mathrm{O}$ and intermediate survival was observed for those with blood types A and B using multivariate analysis, significant associations with lung cancer survival were found for tumor size, positive regional lymphnodes and $\mathrm{ABO}$ blood group. Although some earlier studies have reported associations between malignancies and $\mathrm{ABO}$ blood group system, the results have been inconsistent. Constantini et al. \& Holdsworth et al. ${ }^{19,20}$ have reported poor survival among breast cancer participants with blood type $\mathrm{AB}$ or $\mathrm{B}$ or any non-O blood type. In contrast, Gates et al..$^{21}$ indicated that $\mathrm{ABO}$ blood group was not associated with survival of breast cancer patients. ${ }^{21}$ According to Nozoe et at. ${ }^{22}$ a growing body of plausible mechanisms, including inflammation, immune-surveillance for malignant cells, intracellular adhesion and membrane signalling have been proposed to explain the relationships between $\mathrm{ABO}$ blood group and tumor metastasis and prognosis. ${ }^{22}$

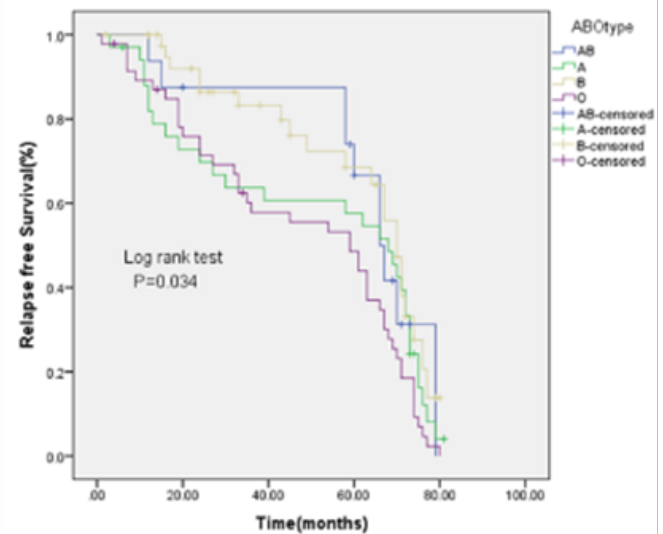

Figure ID Relapse free survival of lung cancer patients according to $A B O$ blood type.

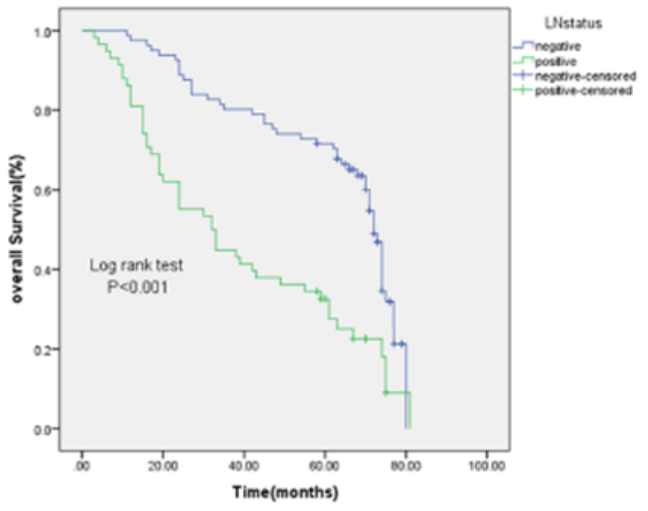

Figure 2A Overall survival of lung cancer patients with lymph nodes status.

The ABO blood type is defined by the carbohydrate moieties displayed on the surface of red blood cells and attached to membrane proteins and lipids. Three variant alleles (A, B and $\mathrm{O}$ ) of a single gene on chromosomes 9q34, the ABO gene determine a person's blood type by encoding three glycosyl transferases with different substrate specificities. Apart from their expression on the surface of red blood cells, the ABO blood antigens are highly expressed on the surface of many epithelial cells, including gastrointestinal, bronchopulmonary, urogenital and skin cells. ${ }^{23,24}$ Alterations of $\mathrm{ABO}$ antigen expression on the surface of cancerous cells, compared with normal 
epithelium, has been demonstrated for a variety of tumor types..$^{23,25}$ Glycosyltransferase specificity has broad implications, beyond explaining ABO blood type. Glycoconjugates are important mediators of intercellular adhesion and membrane signalling, two processes that are integral to malignant progression and spread of cancers. ${ }^{23}$ These surface molecules are also recognized by host immune response and may have a role in facilitating immune-surveillance for malignant cells. ${ }^{26}$

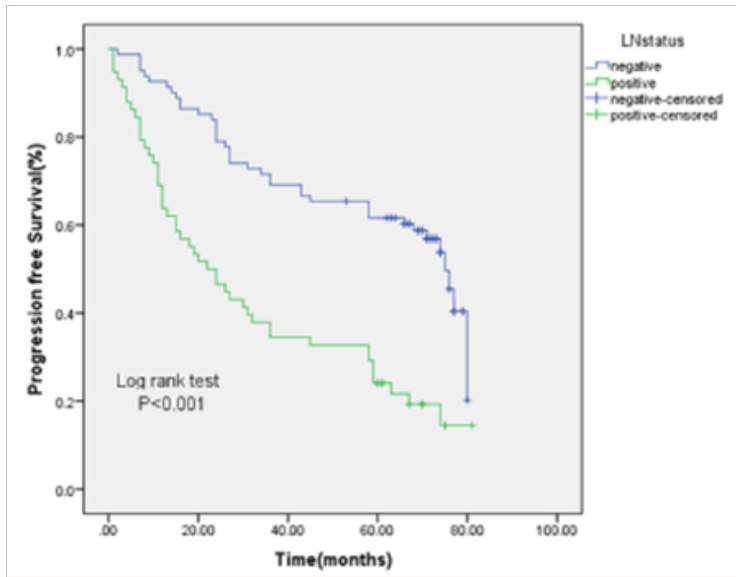

Figure 2B Progression free survival of lung cancer patients according to lymph nodes status.

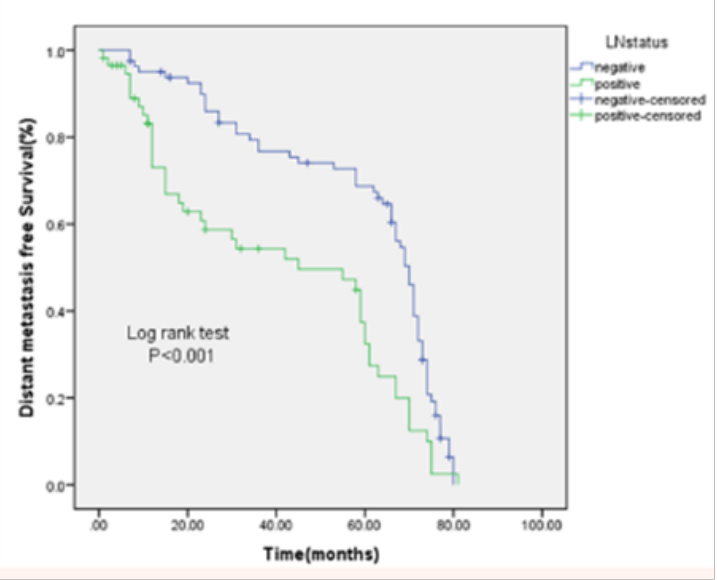

Figure 2C Distant metastasis free survival of lung cancer patients according to lymph nodes status.
Alteration of host inflammatory state due to $\mathrm{ABO}$ blood group antigens may provide a further mechanism to explain the association between $\mathrm{ABO}$ blood group system and lung cancer progression. In recent decades, several studies have demonstrated a link between chronic inflammation and malignant initiation. A study has revealed that an inflammatory cytokine known to modulate cell apoptosis and inhibit tumourigenesis which haa two single-nucleotide polymorphisms at the $\mathrm{ABO}$ locus was associated with serum levels of tumor necrosis factor-alpha. ${ }^{27,28}$ Pare et al. ${ }^{29,30}$ established that there is a statistically significant relationship between single-nucleotide polymorphisms at the ABO locus and plasma levels of intercellular adhesion molecule 1 , a molecule which has classically been associated with functioning inflammatory response. ${ }^{29,30}$ Barbalic et al. \& Qi et al. ${ }^{31,32}$ have studied this finding for other serum markers of inflammation, such as E-selectin and P-selectin. ${ }^{31,32}$ These results reveals the possibility that chronic inflammation is significantly linked with tumor initiation and metastasis and also suggest an additional potential mechanism by which $\mathrm{ABO}$ blood group may influence lung cancer patients survival. This retrospective study has several limitations that should be noted. Firstly, our study population was limited, secondly it was an open-level study and East Asians constitute most of our study population, which somewhat limits the generalizability of our results. Accordingly, the results of further investigations including more diverse populations from other institutes are needed to confirm our findings. Future well designed studies that include diverse ethnic populations are warranted to further analysize the prognostic role of ABO blood group system in Lung cancer patients. Additionally, other potential clinicopathological factors should be considered.

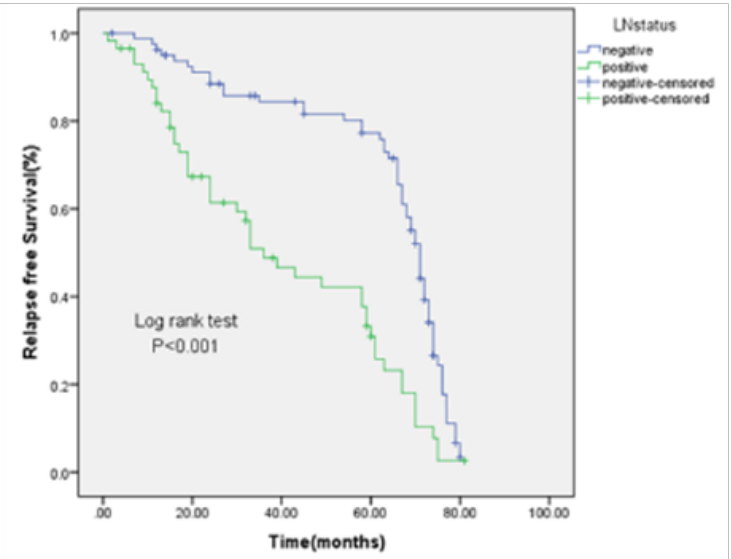

Figure 2D Relapse free survival of lung cancer patients according to lymph nodes status.

Table I Baseline characteristics of I 39 lung cancer patients according to ABO blood type

\begin{tabular}{|c|c|c|c|c|c|c|}
\hline \multirow[t]{3}{*}{ Characteristics } & \multicolumn{2}{|c|}{ All patients } & \multicolumn{3}{|c|}{ Patients ABO blood type } & \multirow[t]{3}{*}{$\mathbf{P}$} \\
\hline & $n=139$ & $A B(\%)$ & $\mathrm{A}(\%)$ & B (\%) & $0(\%)$ & \\
\hline & & $n=16(11.5 \%)$ & $n=34(24.5 \%)$ & $n=42(30.2 \%)$ & $n=47(33.8 \%)$ & \\
\hline \multicolumn{7}{|l|}{ Age } \\
\hline$\leq 60$ Years & 69 & $8(I 1.6 \%)$ & $9(13.0 \%)$ & $26(37.7 \%)$ & $26(37.7 \%)$ & $0.015^{*}$ \\
\hline$>60$ Years & 70 & $8(11.4 \%)$ & $25(35.7 \%)$ & $16(22.9 \%)$ & $21(30.0 \%)$ & \\
\hline \multicolumn{7}{|l|}{ Gender } \\
\hline Male & 95 & $13(13.7 \%)$ & $25(26.3 \%)$ & $27(28.4 \%)$ & $30(31.6 \%)$ & 0.491 \\
\hline Female & 44 & $3(6.8 \%)$ & $9(20.5 \%)$ & $15(34.1 \%)$ & $17(38.6 \%)$ & \\
\hline \multicolumn{7}{|l|}{ Smoking } \\
\hline No & 72 & $8(11.1 \%)$ & $15(20.8 \%)$ & $22(30.6 \%)$ & $27(37.7 \%)$ & 0.698 \\
\hline Yes & 67 & $8(11.9 \%)$ & $19(28.4 \%)$ & $20(29.9 \%)$ & $20(29.9 \%)$ & \\
\hline \multicolumn{7}{|l|}{ Alcohol } \\
\hline No & 88 & $9(10.2 \%)$ & $23(26.1 \%)$ & $27(30.7 \%)$ & $29(33.0 \%)$ & 0.876 \\
\hline
\end{tabular}


Table continued...

\begin{tabular}{|c|c|c|c|c|c|c|}
\hline Characteristics & All patients & & Patients ABO blood type & & & $\mathbf{P}$ \\
\hline Yes & 51 & $7(13.7 \%)$ & $\mathrm{II}(2 \mathrm{I} .6 \%)$ & $15(29.4 \%)$ & $18(35.3 \%)$ & \\
\hline \multicolumn{7}{|l|}{ Tumor Size } \\
\hline$\leq 3 \mathrm{~cm}$ & 50 & $8(16.0 \%)$ & $\mathrm{II}(22.0 \%)$ & $16(32.0 \%)$ & $15(30.0 \%)$ & 0.577 \\
\hline$>3 \mathrm{~cm}$ & 89 & $8(9.0 \%)$ & $23(25.8 \%)$ & $26(29.2 \%)$ & $32(30.0 \%)$ & \\
\hline \multicolumn{7}{|l|}{ pT stage } \\
\hline TI & 43 & $8(18.6 \%)$ & $\mathrm{II}(25.6 \%)$ & $15(34.9 \%)$ & $9(20.9 \%)$ & $0.047 *$ \\
\hline $\mathrm{T} 2$ & 51 & $7(13.7 \%)$ & $9(17.6 \%)$ & $17(33.3 \%)$ & $18(35.3 \%)$ & \\
\hline T3 & 42 & $\mathrm{I}(2.4 \%)$ & $14(33.3 \%)$ & $10(23.8 \%)$ & $17(40.5 \%)$ & \\
\hline $\mathrm{T} 4$ & 3 & $0(0.0 \%)$ & $0(0.0 \%)$ & $0(0.0 \%)$ & $3(100 \%)$ & \\
\hline \multicolumn{7}{|l|}{ Lymphnode Status } \\
\hline Negative & 81 & $10(12.3 \%)$ & $22(27.2 \%)$ & $25(30.9 \%)$ & $24(29.6 \%)$ & 0.631 \\
\hline Positive & 58 & $6(10.3 \%)$ & $12(20.7 \%)$ & $17(29.3 \%)$ & $23(39.7 \%)$ & \\
\hline \multicolumn{7}{|l|}{ Histological Grade } \\
\hline Grade I & 63 & $5(7.9 \%)$ & $17(27.0 \%)$ & $9(14.3 \%)$ & $32(50.8 \%)$ & $0.001 *$ \\
\hline Grade 3 & 18 & $3(16.7 \%)$ & $7(38.9 \%)$ & $6(33.3 \%)$ & $2(11.1 \%)$ & \\
\hline Grade 4 & 4 & $0(0.0 \%)$ & $2(50.0 \%)$ & $2(50.0 \%)$ & $0(0.0 \%)$ & \\
\hline \multicolumn{7}{|l|}{ Differentiation } \\
\hline Poorly & 49 & $7(14.3 \%)$ & $15(30.6 \%)$ & $14(28.6 \%)$ & $13(26.5 \%)$ & 0.673 \\
\hline Moderately & 73 & $7(9.6 \%)$ & $16(21.9 \%)$ & $24(32.9 \%)$ & $26(35.6 \%)$ & \\
\hline Well & 17 & $2(11.8 \%)$ & $3(17.6 \%)$ & $4(23.5 \%)$ & $8(47.1 \%)$ & \\
\hline \multicolumn{7}{|l|}{ Pathological Type } \\
\hline Squamous Cell ca & 52 & $8(15.4 \%$ & $13(25.0 \%)$ & $13(25.0 \%)$ & $18(34.6 \%)$ & 0.128 \\
\hline Adenocarcinoma & 56 & $6(10.7 \%)$ & $\mathrm{II}(19.6 \%)$ & $18(32.1 \%)$ & $21(37.5 \%)$ & \\
\hline Small Cell Carcinoma & 9 & $2(22.2 \%)$ & $2(22.2 \%)$ & $5(55.6 \%)$ & $0(0.0 \%)$ & \\
\hline Bronchoalveolar $\mathrm{Ca}$ & 9 & $0(0.0 \%)$ & I(II.I\%) & $3(33.3 \%)$ & $5(55.6 \%)$ & \\
\hline Other & 13 & $0(0.0 \%)$ & $7(53.8 \%)$ & $3(23.1 \%)$ & $3(23.1 \%)$ & \\
\hline
\end{tabular}

T: tumor

Table 2 Univariate analysis of association between prognosis and ABO blood type and other clinicopathological factors in patients with lung cancer

\begin{tabular}{|c|c|c|c|c|c|c|c|c|c|c|c|c|}
\hline \multirow[t]{2}{*}{ Variables } & \multicolumn{3}{|c|}{ Overall survival(OS) } & \multicolumn{3}{|c|}{ Progression free survival } & \multicolumn{3}{|c|}{$\begin{array}{l}\text { Distant metastasis free } \\
\text { survival(dmfs) }\end{array}$} & \multicolumn{3}{|c|}{$\begin{array}{l}\text { Relapse free } \\
\text { survival(RFS) }\end{array}$} \\
\hline & 5-Year & $\begin{array}{l}\text { Mean } \\
\text { Survival }\end{array}$ & $P$ & $\begin{array}{l}5-\text { Year } \\
\text { PFS }\end{array}$ & $\begin{array}{l}\text { Mean } \\
\text { Survival }\end{array}$ & $\mathbf{P}$ & $\begin{array}{l}\text { 5-Year } \\
\text { DMFS }\end{array}$ & $\begin{array}{l}\text { Mean } \\
\text { Survival }\end{array}$ & $P$ & $\begin{array}{l}5 \text {-year } \\
\text { RFS }\end{array}$ & $\begin{array}{l}\text { Mean } \\
\text { Survival }\end{array}$ & $P$ \\
\hline & (OS)(\%) & (months) & & (\%) & (months) & & (\%) & (months) & & (\%) & (months) & \\
\hline \multicolumn{13}{|l|}{ Age(years) } \\
\hline$\leq 60$ & 31.9 & 54.9 & 0.578 & 42 & 48.7 & 0.479 & 11.6 & 51.3 & 0.555 & 30.4 & 57.6 & 0.142 \\
\hline$>60$ & $30.00 \%$ & 50.5 & & 34.3 & 47 & & 27.1 & 53.3 & & 18.6 & 50.2 & \\
\hline \multicolumn{13}{|l|}{ Gender } \\
\hline Male & 31.6 & 51 & 0.591 & 35.8 & 45.4 & 0.205 & 18.9 & 49.6 & 0.303 & 27.4 & 52.3 & 0.743 \\
\hline Female & 29.5 & 56.3 & & 43.2 & 53.5 & & 20.5 & 57.9 & & 18.2 & 57 & \\
\hline \multicolumn{13}{|l|}{ Smoking } \\
\hline No & 26.4 & 50.2 & 0.116 & 36.1 & 45 & 0.295 & 25 & 52.1 & 0.767 & 23.6 & 49.9 & 0.13 \\
\hline Yes & 35.8 & 55.2 & & 40.3 & 50.9 & & 13.4 & 52.4 & & 25.4 & 58 & \\
\hline \multicolumn{13}{|l|}{ Alcohol } \\
\hline No & 29.5 & 50.2 & 0.371 & 38.6 & 46.2 & 0.646 & 25 & 51.3 & 0.658 & 27.3 & 51.8 & 0.589 \\
\hline Yes & 33.3 & 56.9 & & 37.3 & 51 & & 9.8 & 54 & & 19.6 & 57.1 & \\
\hline \multicolumn{13}{|l|}{ Tumor size } \\
\hline$\leq 3 \mathrm{~cm}$ & 40 & 59.6 & $0.03 I^{*}$ & 40 & 51.8 & 0.403 & 12 & 54.6 & 0.493 & 24 & 58.6 & 0.079 \\
\hline$>3 \mathrm{~cm}$ & 25.8 & 48.7 & & 37.1 & 45.9 & & 23.6 & 50.9 & & 24.7 & 51 & \\
\hline \multicolumn{13}{|l|}{ pT stage } \\
\hline TI & 30.2 & 51.4 & 0.366 & 30.2 & 44 & 0.11 & 25.6 & 53.9 & 0.613 & 32.6 & 51.7 & 0.664 \\
\hline T2 & 33.3 & 57.9 & & 47.1 & 56.2 & & 13.7 & 57 & & 21.6 & 58.8 & \\
\hline T3 & 26.2 & 46.7 & & 33.3 & 40.2 & & 19 & 44.3 & & 21.4 & 49.6 & \\
\hline T4 & 66.7 & 57 & & 66.7 & 54.7 & & 33.3 & 54.7 & & 0 & 52.6 & \\
\hline \multicolumn{13}{|c|}{ Lymphnode status } \\
\hline Negative & 39.5 & 62.2 & $<0.001 *$ & 51.9 & 58 & $<0.001 *$ & 17.3 & 59.2 & $<0.001 *$ & 27.2 & 62.7 & $<0.001 *$ \\
\hline Positive & 19 & 39.2 & & 19 & 33.7 & & 22.4 & 41.1 & & 20.7 & 40.7 & \\
\hline
\end{tabular}

Citation: Nesa EU,Wang C, Rahman CS, et al. Effect of ABO blood group on survival of resected lung cancer patients: a retrospective study. J Cancer Prev Curr Res. 2016;4(I):7-I3. DOI: I0.15406/jcpcr.2016.04.00105 
Table continued...

\begin{tabular}{|c|c|c|c|c|c|c|c|c|c|c|c|c|}
\hline \multirow{2}{*}{$\begin{array}{l}\text { Variables } \\
\text { Histological grade }\end{array}$} & \multicolumn{3}{|c|}{ Overall survival(OS) } & \multicolumn{3}{|c|}{ Progression free survival } & \multicolumn{3}{|c|}{$\begin{array}{l}\text { Distant metastasis free } \\
\text { survival(dmfs) }\end{array}$} & \multicolumn{3}{|c|}{$\begin{array}{l}\text { Relapse free } \\
\text { survival(RFS) }\end{array}$} \\
\hline & & & & & & & & & & & & \\
\hline Grade I & 30.2 & 50.2 & 0.946 & 31.7 & 44.1 & 0.417 & 22.2 & 50.3 & 0.946 & 19 & 50.6 & 0.827 \\
\hline Grade2 & 29.6 & 54.9 & & 40.7 & 51.4 & & 16.7 & 54.2 & & 29.6 & 56.3 & \\
\hline Grade3 & 33.3 & 52.1 & & 44.4 & 46.2 & & 22.2 & 51.2 & & 33.3 & 55.7 & \\
\hline Grade4 & 50 & 60.8 & & 75 & 61.5 & & 0 & 60.2 & & 0 & 60.2 & \\
\hline \multicolumn{13}{|l|}{ Differentiation } \\
\hline Poorly & 28.6 & 46.9 & 0.385 & 38.8 & 43.1 & 0.737 & 30.6 & 50.1 & 0.981 & 20.4 & 48.4 & 0.323 \\
\hline Moderately & 30.1 & 54.7 & & 37 & 48.7 & & I5. I & 52.7 & & 28.8 & 56.2 & \\
\hline Well & 41.2 & 60.2 & & 41.2 & 56.2 & & 5.9 & 55.4 & & 17.6 & 59.3 & \\
\hline \multicolumn{13}{|c|}{ Pathological type } \\
\hline Squamous Cell Ca & 28.8 & 53 & 0.982 & 42.3 & 49.5 & 0.781 & 21.2 & 54.5 & 0.738 & 26.9 & 54.9 & 0.417 \\
\hline Adenocarcinoma & 32.1 & 52.2 & & 32.1 & 45.4 & & 16.1 & 49.2 & & 25 & 53.2 & \\
\hline $\begin{array}{l}\text { Small Cell } \\
\text { Carcinoma }\end{array}$ & 44.4 & 53.3 & & 55.6 & 50.3 & & 33.3 & 62.6 & & 33.3 & 54.2 & \\
\hline Bronchoalveolar $\mathrm{Ca}$ & 11.1 & 61.8 & & 33.3 & 54.3 & & II.I & 58.6 & & 22.2 & 62.4 & \\
\hline Other & 38.5 & 46 & & 38.5 & 43.1 & & 23.1 & 45.1 & & 7.7 & 45.1 & \\
\hline \multicolumn{13}{|l|}{ ABO blood type } \\
\hline$A B$ & 81.3 & 67.9 & $0.024^{*}$ & 62.5 & 62.3 & $0.025^{*}$ & 18.8 & 62.5 & $0.029 *$ & 37.5 & 62.4 & $0.034 *$ \\
\hline A & 32.4 & 52.2 & & 52.9 & 51.3 & & 35.3 & 59.6 & & 11.8 & 50.6 & \\
\hline B & 23.8 & 54.2 & & 38.1 & 47.2 & & 16.7 & 53.1 & & 50 & 60.9 & \\
\hline O & 19.1 & 47.3 & & 19.1 & 41.2 & & 10.6 & 43.6 & & 6.4 & 47.4 & \\
\hline
\end{tabular}

*And bold numbers are statistically significant

T:Tumor; Ca: Carcinoma

Table 3 Multivariate analysis for OS, PFS, DMFS, RFS of lung cancer patients

\begin{tabular}{|c|c|c|c|c|c|c|c|c|c|c|c|c|}
\hline \multirow[t]{2}{*}{ Variables } & \multicolumn{3}{|c|}{ Overall survival(OS) } & \multicolumn{3}{|c|}{$\begin{array}{l}\text { Progression free } \\
\text { survival(PFS) }\end{array}$} & \multicolumn{3}{|c|}{$\begin{array}{l}\text { Distant metastasis free } \\
\text { survival(DMFS) }\end{array}$} & \multicolumn{3}{|c|}{ Relapse free survival(RFS) } \\
\hline & $\mathrm{HR}$ & $95 \% \mathrm{Cl}$ & $P$ & $\mathrm{HR}$ & $95 \% \mathrm{Cl}$ & $P$ & $\mathrm{HR}$ & $95 \% \mathrm{Cl}$ & $P$ & $\mathrm{HR}$ & $95 \% \mathrm{Cl}$ & $P$ \\
\hline $\begin{array}{l}\text { Tumor size } \\
(\leq 3 \mathrm{~cm} \mathrm{Vs}>3 \mathrm{~cm}\end{array}$ & 0.626 & $0.404-0.970$ & $0.036^{*}$ & 0.828 & $0.530-1.294$ & 0.408 & 0.878 & $0.598-1.290$ & 0.507 & 0.71 & $0.475-1.056$ & 0.09 \\
\hline $\begin{array}{l}\text { Histological grade } \\
\text { Gradel and } 2 \text { Vs } \\
\text { Grade } 3 \text { and } 4\end{array}$ & 1.477 & $0.323-6.752$ & 0.615 & 2.819 & $0.358-22.175$ & 0.325 & 0.748 & $0.242-2.312$ & 0.614 & 1.13 & $0.356-3.579$ & 0.836 \\
\hline $\begin{array}{l}\text { Differentiation } \\
\text { Poorly Vs Well and } \\
\text { Moderately }\end{array}$ & 1.886 & $0.772-4.603$ & 0.164 & 1.92 & $0.790-4.668$ & 0.15 & 1.224 & $0.548-2.736$ & 0.623 & 1.14 & $0.60 I-2.969$ & 0.477 \\
\hline $\begin{array}{l}\text { PT stage } \\
\text { TIT2 Vs T3T4 }\end{array}$ & 3.358 & $0.431-26.138$ & 0.247 & 4.408 & $0.563-34.519$ & 0.158 & 2.086 & $0.456-9.536$ & 0.343 & 1.53 & $0.412-1.663$ & 0.526 \\
\hline $\begin{array}{l}\text { Lymphnode status } \\
\text { Negative Vs } \\
\text { positive }\end{array}$ & 0.395 & $0.252-0.617$ & $<0.00 I^{*}$ & 0.388 & $0.244-0.617$ & $<0.001 *$ & 0.464 & $0.303-0.711$ & $<0.001 *$ & 0.38 & $0.242-0.586$ & $<0.00 I^{*}$ \\
\hline ABO blood type & 0.159 & $0.046-0.543$ & $0.003 *$ & 0.313 & $0.122-0.801$ & $0.015^{*}$ & 0.301 & $0.160-0.568$ & $<0.001 *$ & 0.48 & $0.274-0.852$ & $0.012^{*}$ \\
\hline
\end{tabular}

*and bold numbers means statistically significant

HR: Hazard Ratio; Cl: Confidence Interval;T:Tumor

\section{Conclusion}

Our results suggested that the ABO blood types were significantly associated with lung cancer patients survival. In contrast to patients of $\mathrm{AB}$ blood type with non-AB (blood type A, B, O), patients with blood type $\mathrm{AB}$ were more likely to have a better OS, PFS, DMFS and RFS. The impact of $\mathrm{ABO}$ blood type on malignant potential and prognosis in patients with lung cancer remains an interesting area of research, which warrents additional investigations.

\section{Acknowledgements}

None.

\section{Conflicts of interest}

The authors declare that there is no conflict of interest.

\section{References}

1. Jemal A, Bray F, Center MM, et al. Global Cancer Statistics. CA Cancer J Clin. 2011;61:69-90.

2. Siegel R, DeSantis C, Virgo K, et al. Cancer treatment and survivorship statistics. CA Cancer J Clin. 2012;62(4):220-241.

3. Yazer MH. What a difference 2 nucleotides make: a short review of ABO genetics. Transfus Med Rev. 2005;19(3):200-209.

Citation: Nesa EU,Wang C, Rahman CS, et al. Effect of ABO blood group on survival of resected lung cancer patients: a retrospective study.J Cancer Prev Curr Res. 2016;4(I):7-13. DOI: 10.15406/jcpcr.2016.04.00105 
4. Itzkowitz SH, Yuan M, Ferrell LD, et al. Cancer-associated alterations of blood group antigen expression in the human pancreas. J Natl Cancer Inst. 1987;79(3):425-434

5. Matsumoto H, Muramatsu $\mathrm{H}$, Shimotakahara $\mathrm{T}$, et al. Correlation of expression of $\mathrm{ABH}$ blood group carbohydrate antigens with metastatic potential in human lung carcinomas. Cancer. 1993;72(1):75-81.

6. Wolpin BM, Chan AT, Hartge P, et al. ABO blood group and the risk of pancreatic cancer. J Natl Cancer Inst. 2009;101(6):424-431.

7. Rahbari NN, Bork U, Hinz U, et al. AB0 blood group and prognosis in patients with pancreatic cancer. BMC Cancer. 2012;12:319.

8. Cao X, Wen ZS, Sun YJ, et al. Prognostic value of ABO blood group in patients with surgically resected colon cancer. Br J Cancer. 2014;111(1):174-180.

9. Ouyang PY, Su Z, Mao YP, et al. Prognostic value of ABO blood group in southern Chinese patients with established nasopharyngeal carcinoma. Br J Cancer. 2013;109(9):2462-2466.

10. Cihan YB. Significance of ABO-Rh blood groups in response and prognosis in breast cancer patients treated with radiotherapy and chemotherapy. Asian Pac J Cancer Prev. 2014;15(9): 4055-4060.

11. Qin J, Wu SG, Sun JY, et al. Effect of blood type on survival of Chinese patients with esophageal squamous cell carcinoma. Onco Targets and therapy. 2015;8:947-953.

12. Hoskins LC, Loux HA, Britten A, et al. Distribution of ABO blood groups in patients with pernicious anemia, gastric carcinoma and gastric carcinoma associated with pernicious anemia. $N$ Engl J Med. 1965;273(12):633-637.

13. Xie J, Qureshi AA, Li Y, et al. ABO blood group and incidence of skin cancer. PLoS One. 2010;5(8):e11972.

14. Kaffenberger SD, Morgan TM, Stratton KL, et al. ABO blood group is a predictor of survival in patients undergoing surgery for renal cell carcinoma. BJU Int. 2012;110(11 Pt B):E641-E646.

15. Lee JS, Ro JY, Sahin AA, et al. Expression of blood-group antigen A-a favorable prognostic factor in non-small cell lung cancer. $N$ Engl J Med. 1991;324(16):1084-1090.

16. Fukumoto K, Taniguchi T, Usami N, et al. The ABO Blood Group is an Independent Prognostic Factor in Patients With Resected Non-small Cell Lung Cancer. J Epidemiol. 2015;25(2):110-116.

17. Shepherd FA, Crowley J, Van Houtte P, et al. The International Association for the Study of Lung Cancer lung cancer staging project: proposals regarding the clinical staging of small cell lung cancer in the forthcoming (seventh) edition of the tumor, node, metastasis classification for lung cancer. $J$ Thorac Oncol. 2007;2(12):1067-1077.
18. Liumbruno GM, Franchini M. Hemostasis, cancer and ABO blood group: the most recent evidence of association. J Thromb Thrombolysis. 2014;38(2):160-166.

19. Costantini M,FassioT, CanobbioL, etal.Roleofblood groupsas prognostic factors in primary breast cancer. Oncology.1990;47(4):308-312.

20. Holdsworth PJ, Thorogood J, Benson EA, et al. Blood group as a prognostic indicator in breast cancer. $\mathrm{Br}$ Med $J$ (Clin Res Ed). 1985;290(6469):671-673.

21. Gates MA, Xu M, Chen WY, et al. ABO blood group and breast cancer incidence and survival. Int J Cancer. 2012;130(9):2129-2137.

22. Nozoe T, Ezaki T, Baba H, et al. Correlation of ABO blood group with clinicopathologic characteristics of patients with esophageal squamous cell carcinoma. Dis Esophagus. 2004;17(2):146-149.

23. Hakomori S. Antigen structure and genetic basis of histo-blood groups $\mathrm{A}, \mathrm{B}$ and $\mathrm{O}$ : their changes associated with human cancer. Biochim Biophys Acta. 1999;1473(1):247-266.

24. Le Pendu J, Marionneau S, Cailleau-Thomas A, et al. ABH and Lewis histo-blood group antigens in cancer. APMIS. 2001;109(1):9-31.

25. Strauchen JA, Bergman SM, Hanson TA. Expression of A and B tissue isoantigens in benign and malignant lesions of the breast. Cancer. 1980;45(8):2149-2155.

26. Hakomori S. Tumor-associated carbohydrate antigens defining tumor malignancy: basis for development of anti-cancer vaccines. Adv Exp Med Biol. 2001;491:369-402.

27. Locksley RM, Killeen N, Lenardo MJ. The TNF and TNF receptor super families: integrating mammalian biology. Cell. 2001;104(4):487-501.

28. Melzer D, Perry JR, Hernandez D, et al. A genome-wide association study identifies protein quantitative trait loci (pQTLs). PLoS Genet. 2008;4(5):e1000072.

29. Paré G, Chasman DI, Kellogg M, et al. Novel association of ABO histoblood group antigen with soluble ICAM-1: results of a genome-wide association study of 6, 578 women. PLoS Genet. 2008;4(7): e1000118.

30. Yang L, Froio RM, Sciuto TE, et al. ICAM-1 regulates neutrophil adhesion and transcellular migration of TNF-alpha-activated vascular endothelium under flow. Blood. 2005;106(2):584-592.

31. Barbalic M, Dupuis J, Dehghan A, et al. Large-scale genomic studies reveal central role of ABO in SP-selectin and sICAM-1 levels. Hum Mol Genet. 2010;19(9):1863-1872

32. Qi L, Cornelis MC, Kraft P, et al. Genetic variants in ABO blood group region, plasma soluble E-selectin levels and risk of type 2 diabetes. Hum Mol Genet. 2010;19(9):1856-1862. 